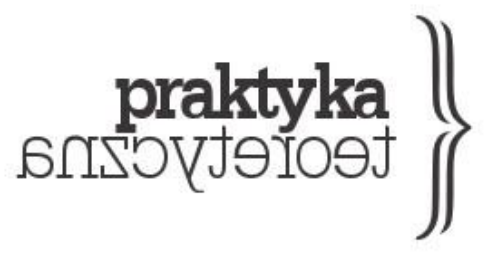

ISSN 2081-8130

DOI: $10.14746 /$ prt.2016.4.7 www.praktykateoretyczna.pl

\title{
HISTORIA I STRUKTURA. PROBLEM UPRAWOMOCNIENIA
}

\author{
ANDRZEJ LEDER
}

\begin{abstract}
Abstrakt: Zarysowany przez de Saussure'a spór pomiędzy myśleniem strukturalistycznym a historycznym autor rozpoznaje jako konflikt zasad etycznych w filozofii społecznej. Pokazuje, jak każda z tych zasad generuje inną ontologię społecznego bytu. Na przykładzie Deleuze'a rozważa teoretyczne umiejscowienie każdej z tych etycznych pozycji, a potem, w oparciu o myśl poststrukturalistyczną, a szczególnie Lacanowską, próbuje naszkicować teoretyczną przestrzeń, w której takie zmiany pozycji etycznej byłyby możliwe. Wypracowuje w ten sposób pewną filozofię pól symbolicznych.
\end{abstract}

Słowa kluczowe: de Saussure, Deleuze, Benjamin, historia, struktura, etyka, pole symboliczne 
Podstawowy mankament każdego systemu dualistycznego, a w szczególności Kantowskiego, przejawia się w postaci niekonsekwencji polegającej na łączeniu tego, co przed chwilą uznane zostało za samoistne, a zatem za nie dajace sie połacsyćc. Ledwie tylko to, co połączone, zostało uznane za prawdziwe, a już w chwile potem za prawdziwe uznane jest raczej to, że oba momenty, którym w połączeniu jako ich prawdzie odmówiono trwałego-istnienia-dla-siebie (das Fur-sich-Bestehen), mają prawdę i rzeczywistość o tyle, o ile są oddzielone (Hegel 1990, 119).

G.W.F. Hegel

\section{Ekspozycja}

Kwestia zmiany historycznej jest dla każdego konsekwentnego strukturalizmu problemem. W dwudziestym wieku spór zaczął się wraz ze znanym zdaniem Ferdinanda de Saussure'a: „opozycja między dwoma punktami widzenia - synchronicznym i diachronicznym - jest absolutna i nie dopuszcza żadnych kompromisów" (de Saussure 1991, 107). Pamiętać trzeba, że zdanie to wypowiedział językoznawca na przełomie dziewiętnastego i dwudziestego wieku, w momencie prymatu różnego rodzaju historyzmów w humanistyce - od pozytywistycznego niemieckiej szkoły historycznej, przez materializm historyczny, po ten obecny w językoznawstwie. Teleologia historii wówczas dominowała. Pozycja de Saussure’a była więc przełomem. Nawet bowiem jeśli - za uczniami genewskiego językoznawcy - odpierać będzie się ataki zwolenników diachronii w języku - ze szkoły praskiej na przykład - przez podkreślanie, że w zdaniu tym „chodzi o dwa punkty widzenia na język, nie zaś o przeciwstawienie aspektu synchronicznego i diachronicznego w samym jezzyku” (de Saussure 1991, 107, przyp. 5), to problem pozostaje. Wiemy przecież, że w nauce, a w humanistyce w szczególności, rozstrzygnięcia metodologiczne decydują o ontologicznym statusie przedmiotu, w pewnym sensie determinują sposób jego istnienia. Jeśli więc przyjmujemy, że opozycja dwóch metodologicznych punktów widzenia ,jest absolutna” i „nie dopuszcza żadnych kompromisów”, to uznajemy pośrednio, że wyłaniane są całkowicie różne obiekty rozmyślania; co więcej, że nie ma przejścia pomiędzy jednym z tych obiektów a drugim. Jeśli na dodatek wybieramy któryś z tych punktów widzenia i uznajemy jego prymat, jeśli rozwijamy jego teoretyczne opracowanie, pozostawiając spostrzeżenia na temat tego drugiego jakby „na marginesach”, to w oczywisty sposób ustanawiamy go jako rzeczywistość pierwotna, określającą wszystkie możliwości zdarzeń. 
Taki też był rozwój „ortodoksyjnie” traktowanego strukturalizmu. Obraz, który owa ortodoksja rozwijała, bardzo precyzyjnie uchwycił Gilles Deleuze:

[...] nie tylko przedmiot rzeczywisty i wyobrażony, ale ich wzajemne stosunki oraz zaburzenia tych stosunków powinny być pomyślane jako granica pewnego procesu [podkreśl. AL], w którym punktem wyjścia jest coś symbolicznego. U Lacana, podobnie jak u innych strukturalistów, żywiołem struktury jest żywioł symboliczny i on to leży u początków genezy [...] (Deleuze 1978, 289).

Właściwie już tu wszystko jest powiedziane. Struktura, „żywioł symboliczny”, leży u początków genezy, czyli wszelkiego procesu dziejowego, co więcej: wszystko, co się zdarza, jest „granicą procesu”, nie może on wyjść poza stosunki i zaburzenia stosunków określone przez strukturę, i tylko w jej ramach konstytuują się przedmioty, rzeczywiste i wyobrażone. Nic więc dziwnego, że:

[...] struktura wciela się w przedmioty rzeczywiste i obrazy, których ciagi zawsze daja się określić; co więcej, w tym wcieleniu ustanawia je, nigdy nie będąc ich pochodna, skoro leży głębiej niż one, skoro jest podglebiem dla wszystkich ziemskich warstw rzeczywistości i wszystkich niebieskich sfer wyobraźni (Deleuze 1978, 289).

Paradoksalnie i zapewne wbrew intencjom Deleuze'a takie postawienie sprawy może ostatecznie uzasadniać tezy Kojève’a czy Fukuyamy o możliwym końcu historii. Jeśli bowiem wszystkie pozycje w strukturze zostaną wypełnione, jeśli każde możliwe w danym systemie symbolicznym wydarzenie już się wydarzy, a przecież ,jest [ów system - przyp. AL] podglebiem dla wszystkich ziemskich warstw rzeczywistości”, już nie mówiąc o wyobraźni, to skazani będziemy tylko na powtórzenie, w ramach tej samej struktury, tych samych rzeczy, zdań, czynów, katastrof...

\section{Nauki: od przesłanek ontologicznych do etycznego uprawomocnienia}

Wszelka pozytywnie rozumiana naukowość opiera się na postulatach dotyczących ontologii. Mimo tego, że głębokie uprawomocnienie czerpie ze sfery etycznej, w swojej mowie odwołuje się do obrazu tego-co-istnieje, faktu. Zanim podejmiemy się uzasadnienia tezy o uprawomocnieniu nauki przez przesłankę etyczna, zwrócimy uwagę na jeden przykład tego, jak ontologiczne założenia niedostrzegalnie penetrowały wszelkie projekty myślowe, również 
te dotyczące filozofii społecznej. Nieprzypadkowo jeden z ważnych głosów w sporze o tę dziedzinę, głos Györgya Lukácsa, nazywał się Ontologią bytu społecænego. Ten tytuł był jednocześnie postulatem - byt społeczny ma swoje istnienie; i jak każde istnienie ma swoje prawa, reguły, dialektykę...

Ukryte przesłanki ontologiczne tkwiące w metodologii nowoczesnych nauk przedstawił Martin Heidegger. Przypomnijmy: w pracy Kant a problem metafizyki wykazał on, że Kantowska Krytyka ç̧ystego rozumu kryje w sobie projekt ontologii. Ujął to w taki sposób: „ontologia nie jest niczym innym jak wyraźnym odsłonięciem systematycznej całości czystego poznania, skoro poznanie owo kształtuje transcendencje”" (Heidegger 1989, 140). Gdy tworzymy całościowy projekt wyjaśniający genezę wszelkiego fenomenu, wszelkiej rzeczy, wiemy już wszystko o naturze jej istnienia, a to oznacza, że dysponujemy ontologia. Rozumowanie to przenieść możemy na „transcendentalizm bez podmiotu”, jak czasem nazywa się strukturalizm. Jeśli naukowa praktyka strukturalizmu polegać miała na odsłonięciu „żywiołu symbolicznego” wcielającego się we wszystkie przedmioty „rzeczywiste i wyobrażone", a więc - w sensie fenomenologicznym - transcendentne ${ }^{1}$, jeśli miała odsłonić całość tego „podglebia” kształtującego poznanie, to nie była niczym innym niż ontologia. Co najmniej w takim sensie, w jakim ontologie rozumiał Heidegger.

Wcześniej, wpisując Kantowski transcendentalizm w dzieje, Hegel otworzył droge dla najbardziej filozoficznego nurtu historyzmu dziewiętnastego stulecia. Ontologia bytu społecznego mogła nabrać charakteru dialektycznego i historycznego. Atoli przywołanie Hegla nie jest tylko oddaniem sprawiedliwości roli, jaką odegrał w rozwoju myślenia historiozoficznego. Dla nas równie ważne jest to, że Hegel znakomicie ilustruje, jak gest filozoficzny ustanawiający pewną ontologię ostatecznie opiera się na przesłance etycznej.

Na czym polega ten związek? Jak ujął to Charles Taylor, chodzi o to, by „sposób istnienia rzeczy ustalał dla nas [...] normy i standardy" (Taylor 2001, 299), to znaczy by to, jak obiekty, postaci i sprawy nam się jawią, miało dla nas znaczenie moralne i wyznaczało ramy porządku etycznego. W nowożytności właśnie przyszłość miała mieć „normatywną moc" (Taylor 2001, 299). Mogła ona legitymizować, albo inaczej - usprawiedliwiać, nasze praktyki społeczne i samo nasze istnienie.

Przez wieki myślenie filozoficzne uznawało metafizyczną regułę, zgodnie z którą przyczyna ma zawsze „więcej rzeczywistości” niż skutek. Wiązało się z tym jednak również przyjęcie tego, że ilość dobra jest większa wcześniej niż później. Porządek normatywny ujawniany przez taką ontologię zakorzenia się więc w przeszłości, w mitycznej epoce „złotej”

\footnotetext{
1 Wszelkie istnienie przedmiotowe, tak postrzeżenie jak wyobrażenie, jest z perspektywy fenomenologicznej transcendentne w stosunku do struktury świadomości. Tę konstrukcję Heidegger wykorzystuje do interpretacji filozofii Kanta.
} 
albo w czasie przed upadkiem. Wprowadzając logiczną konstrukcję zniesienia (Aufhebung), Hegel stworzył narzędzie pozwalające przenosić w przyszłość rdzeń rzeczywistości, która przemijała. Oznaczało to, że przyszłość będzie miała „więcej rzeczywistości” niż przeszłość, a więc również więcej dobra. Powstała ontologia uzasadniająca etyczny prymat przyszłości, teleologię historii. Konsekwencje polityczne tego etycznego odwrócenia są oczywiste.

Grając ze znaną formułą Reinhardta Kosselecka - „,...] nie istnieje historia, którą można by konstruować bez doświadczeń i oczekiwań działających lub cierpiących [podkreśl. AL] ludzi [...]” (Kosseleck 2001, 361) - Jürgen Habermas pokazuje, jak owa konstrukcja filozoficzna określa nowożytny stosunek do historii:

\section{Otwarty ku przyszłości horyzont określonych przez teraźniejszość oczekiwań kieruje naszym dostępem do przeszłości [podkreśl. AL] [...]. Dla tej świadomości konstytutywne są dwa momenty: po pierwsze, przynależna do historii oddziałującej więź ciagłych dziejów przekazu, w których osadzony jest nawet czyn rewolucyjny; po drugie, dominacja horyzontu oczekiwań nad przyswajanym potencjałem doświadczeń historycznych [podkreśl. AL] (Habermas 2000, 23)}

$\mathrm{Na}$ czym polega „dominacja horyzontu oczekiwań nad przyswajanym potencjałem doświadczeń"? Albo szerzej: w jaki właściwie sposób jeden wymiar czasu może dominować nad drugim? Szczególnie gdy fundamentalnie różnią się statusem logicznym. Gdzie zatem jest owa arena, na której się spotykają? Odpowiedź zaczerpnąć można właśnie z formuły Taylora: to wymiar etyczny umożliwia spotkanie tego, co dopiero będzie, z tym, co było. On bowiem stwarza zasadę, pole, przestrzeń pozwalająca na gesty porównania - a więc sprowadzenia dwóch rzeczy całkowicie różnych przed jeden trybunał - i sądzenia.

Wymiar ten w myśleniu nowożytnym ustanowił również prymat przyszłości, ta bowiem miała przynieść sprawiedliwość, zaś związana z nią nadzieja - zamieniona w pewność - pozwalała sądzić przeszłość. Jawił się on jednocześnie jako ściśle polityczny, dlatego nazywać go można etyczno-politycznym.

Trzeba zauważyć, że w ten sposób uznaliśmy etyczny prymat pragnienia $^{2}$, w tej konstrukcji ono właśnie określa naszą sytuację w sposób najistotniejszy. „Dominacja horyzontu oczekiwań” w całkowitej pustce wyznacza zręby naszych przyszłych gestas. Dopiero w następnym kroku ta etyczno-polityczna wizja przyszłości pozwala na uporządkowanie przeszłych doświadczeń, ona „kieruje naszym dostępem do przeszłości”. Można więc powiedzieć, że moje-spojrzenie-woku-Innego - stanowiące rdzeń sytuacji etycznej - w nowożytności ulokowane jest w czasie

\footnotetext{
${ }^{2}$ Kursywą zapisuję pojęcia wywodzące się z teorii Lacanowskiej, by zaznaczyć ich użycie inne niż intuicyjne.
} 
przyszłym i dopiero przenikając stamtąd, teraźniejszość dokonuje oceny przeszłości. Istnienie przyszłego wymiaru uprawomocnia dzieje i nadaje im ontologicznej spoistości - gwarantowanej przez linearny charakter czasu historycznego - która do końca dziewiętnastego wieku wydawała się tak oczywista, że pozostawała zupełnie niewidoczna.

Czas przyszły, możliwy tylko jako funkcja pragnienia, jawił się jako oczywistość istnienia przyszłości ${ }^{3}$ Etyczna delegitymizacja przyszłości poddała próbie jej ontologiczną moc. Atoli gdy przyszłość traci swoją ontologiczną samoistność, również pragnienie zaczyna kruszeć i się „rOzszczelniać”.

Rozumowanie Taylora można więc odwrócić. Oto, twierdzi on, w sposobie jawienia się rzeczy rozpoznajemy zasadę etyczną, która je uprawomocnia. Jeśli jednak pewna zasada straci swoją etyczną moc, rzeczy zaczną nam się jawić w inny sposób. Jakby w innym świetle. Tak można rozumieć „zluzowanie” historyzmu przez strukturalizm w latach sześćdziesiątych przeszłego stulecia.

Rozkład sił w polu etycznym zmienił się, gdy porzuciliśmy perspektywę teleologiczną i zamiast ciagłego procesu stawania-się w rzeczach rozpoznawać zaczęliśmy węzły porządku symbolicznego. Zmieniliśmy tym samym nie tylko nasz sposób rozumienia „systematycznej całości czystego poznania”, czyli ontologię, warunkująca „rzeczy i wyobrażenia”. Zmieniliśmy też regułę etyczną, którą odczytujemy w „sposobie istnienia rzeczy”. W tym sensie „zluzowanie” historycyzmu przez strukturalizm lat sześćdziesiątych dwudziestego stulecia pozwala nam domyślać się nowej reguły etycznej, legitymizującej nową, tym razem strukturalistyczną ontologię, „sposób istnienia społecznej rzeczy”. Reguły zmieniającej też cele i uzasadnienia działań politycznych.

\section{Zmierzch etycznego uprawomocnienia nauk}

Antyteleologiczny, kwestionujący etyczno-polityczne uprawomocnienie wszelkiego historyzmu potencjał myśli strukturalistycznej rozpoznali znakomicie Alain Renaut i Luc Ferry, rekonstruujący „dwadzieścia lat później” historię francuskiej filozofii ‘68. Pisali:

Lévi-Strauss oczywiście ostro krytykował idę teleologii historii, która ciągle dominowała w marksizmie, pokazując nieuchronnie eurocentryczne konsekwencje takiej teleologii,

\footnotetext{
3 Związek między przyszłością, czy - szerzej - przepływem czasu, a pragnieniem, wymagałby oddzielnego opracowania. Najprościej mówiąc, ten, kto nie ma pragnienia, nie doświadcza też temporalnego przepływu. To dlatego Freudowski melancholik tkwi w swoistym „bezczasie”, w wiecznym „teraz”, poza przyszłością i przeszłością.
} 
czyniące $\mathrm{z}$ najbardziej uprzemysłowionych narodów jedyny możliwy model dla społeczeństw pierwotnych, społeczeństw, które z tej perspektywy nieuchronnie postrzegane były raczej jako słabo rozwinięte niż inne albo różne (Renaut i Ferry 1990, 5)4.

Kryzys myślenia historycznego i wysunięcie się strukturalizmu na pozycję najważniejszej metodologii nauk humanistycznych w połowie dwudziestego wieku nie doprowadziły jednak do zakwestionowania moralnej prawomocności nauki jako takiej. Wręcz przeciwnie. Jak bardzo surowym krytykiem teleologii historii nie byłby Claude Lévi-Strauss, pozostawał on jak najdalej od „zluzowania” prymatu „faktyczności” w myśleniu teoretyków nauk społecznych i humanistów. Łączył z tak rozumianą naukowością strukturalistycznej humanistyki wielkie nadzieje:

[...] w zbiorze nauk społecznych, do których językoznawstwo bezsprzecznie należy, zajmuje ono wszakże wyjątkowe miejsce; nie jest nauką społeczna jak inne, lecz tą, która osiagnęła największe postępy; jest chyba jedyna, która może pretendować do miana nauki i która zdołała sformułować pozytywną metodę a zarazem poznać naturę faktów poddawanych przez nią analizie (Lévi-Strauss 1970, 89).

Jesteśmy jednak w następnym stuleciu. To jest historyczna pozycja, z której spoglądamy. Rozpoznanie w drugiej połowie dwudziestego wieku zbrodni popełnianych w imię nauk - tak nauk przyrodniczych, obejmujących antropologie fizyczne dziewiętnastego stulecia z ich rasistowskim ukoronowaniem, jak społecznych, z teoria postępu i rewolucji - kładło się cieniem na pozytywistycznym optymizmie.

Zatem chwilę po tym, jak Lévi-Strauss zadekretował nowa naukowość humanistyki, Jacques Derrida zarzucił mu mieszanie porządku uzasadnień filozoficznych z porządkiem rzeczy, faktów (Derrida 1999, 225). „Nieodróżnienie faktu i prawa jest błędem par excellence filozoficznym" - pisze o tej polemice Vincent Descombes, podkreślając etyczną konotację słowa „błąd” (Descombes 1997, 166-167).

Oto według Derridy empirycyzm, grzech każdego, kto chce z opisu tego-co-jest wyprowadzać regułę, ostatecznie jawi się jako uznanie faktu, że „siła tworzy prawo”. Dlatego właśnie, nie chcąc uznać na wzór Nietzscheańskiej prawotwórczej władzy przemocy, poszukiwał Derrida stricte filozoficznej konstrukcji opowiadającej o genezie wszelkiego porządku.

\footnotetext{
4 "Lévi-Strauss did indeed vigorously criticize the idea of a teleology of history, to which Marxism was still captive, demonstrating the inevitably Eurocentrist consequences of such a teleology which made the most industrially developed nations the only possible model for primitive societies, societies that were, from this perspective, then inevitably regarded as underdeveloped rather than as other or different."
} 
Zaznaczyć trzeba, że empirycyzm nie może być tu rozumiany wyłącznie jako naturalizm. Również różnego rodzaju formalizmy, łącznie z formalizmem matematycznym, podlegają krytyce przedstawionej przez Derridę. Dotyczy to więc także formalizmu strukturalistycznego. Ów formalizm zakłada bowiem, że da się wywieść wszelkie prawdy łącznie z Prawdą jako fundamentalną norma poznania - z formalnych mechanizmów genezy tych prawd. Charakterystyczne dla tego sposobu myślenia przekonanie, że pewne pozytywnie opisane modele genezy znaczeń mogą być odpowiedzią na podstawowe pytania filozoficzne, jest więc jednoznaczne z uznaniem, że siła faktu może mieć charakter normatywny. Faktem jest tu nierozerwalny związek między pewnym symbolicznym - w strukturalistycznym sensie - formalizmem a jego rezultatem: konkretna formą znacząca. Kluczowa teza tego stylu myślenia mówi więc, że opisując warunki pojawienia się pewnego fenomenu, wiemy o nim wszystko. Możemy w ten sposób udzielać odpowiedzi na wszelkie pytania filozoficzne. Ta teza pozytywnej naukowości łączy w gruncie rzeczy teleologię historii z formalizmem struktury.

Derrida przekornie odpowiada: „Coś, czego nigdy nie mogę zrozumieć w pewnej strukturze, jest tym właśnie, co powoduje, że nie jest ona zamknięta” (Descombes 1997, 166167). A następnie dodaje:

\begin{abstract}
Idea czy projekt ożywiające wszelką zdeterminowana strukturę historyczną [czyli pewien model genezy - przyp. AL], wszelką Weltanschaung, są skończone: wychodząc od strukturalnego opisu pewnej wižji śniata, da się więc uchwycić wszystko, wyjąwszy owo nieskończone otwarcie się na prawdę, czyli filozofię (Derrida 2004, 276).
\end{abstract}

To właśnie, co Derrida nazywa „strukturą zamkniętą”, ma opowiadać o konkretnej, a jednocześnie koniecznej genezie pewnego zjawiska. Zauważmy, że spełnienie wymogu jasności obliguje do tego, by była ona skończona, inaczej dany fenomen nie jawiłby się w swojej konkretności i jednoznaczności (do tej kwestii będziemy musieli wrócić). Ale jednocześnie, uparcie powtarza za Husserlem Derrida, filozofia, otwarcie na prawdę, nie tkwi w tym konkretnym opisie, lecz właśnie w tym, czego w nim „nie mogę zrozumieć”.

Cytowane powyżej zdania formułuje Derrida, opisując polemikę twórcy fenomenologii z koncepcjami Wilhelma Diltheya. Zwraca uwage na to, że Husserl „zawzięcie” przeciwstawia się przekonaniu o kompletności i wystarczalności takiego projektu. Twierdzi, że od filozofii oddziela go pewna drobna różnica, jak pisze - małe „nic”. I dodaje: „Ta nieusuwalna różnica wynika z jakiegoś nie mającego końca opóźniania [différance] podstawy teoretycznej” (Derrida 2004, 278). 
Charakter tego „opóźniania” ujęty jest w bardzo szczególny sposób. Otóż wiedza pozytywna, naukowa, nawet wiedza najbardziej teoretyczna i dotycząca spraw najbardziej ogólnych, musi dać odpowiedź wymaganiom życia historycznego, rzeczywistego. Jeśli nawet pogodzimy się z tym, że tak rozumiana wiedza nie ma zmieniać świata, to wciąż ma go co najmniej wyjaśniać. Wyjaśniać ludziom żyjącym dzisiaj, wyjaśniać za pomocą tych odpowiedzi, których teraz może udzielić. Tak rozumie swój obowiązek. I dlatego właśnie cechuje ja „pewna zapobiegliwość, pewien pośpiech etyczny [podkreśl. AL]” (Derrida 2004, 278). Dla pozytywnie myślącego uczonego wiedza nie może odraczać odpowiedzi.

Takie jest $\mathrm{w}$ istocie moralne uprawomocnienie nauki pozytywnej, uprawomocnienie, które uznawał nawet Husserl ${ }^{5}$. Uprawomocnienie, które tym razem nie czerpie siły z przyszłości, ale z etycznych wymogów chwili teraźniejszej. Atoli filozofia nie może czuć tego zobowiązania. Powołaniem filozofii jest wytrzymanie presji owego pytania, które w życiu domaga się natychmiastowej odpowiedzi. Właśnie wytrzymując tę potężną presję, unikając „etycznego pośpiechu”, tworzy filozofia swoją własną przestrzeń.

Wprowadzając to rozróżnienie, stawia Derrida - mimochodem - tezę o wielkiej wadze. Mówi bowiem, że a priori odróżniające wszelką wiedzę pozytywną od filozofii jest rodzajem etycznego nastawienia. Ma charakter etyczny. I nie jest to jałowe moralizowanie ani jednoznaczne wartościowanie którejkolwiek z dwóch postaw: teoretycznego pośpiechu versus opóźniania. W dyskusji Husserla z pozytywistyczną historiozofią odnajduje Derrida dramatyczny dylemat pomiędzy „praktycznym przymusem, by zająć stanowisko”, a odmowa zgody na tego rodzaju przymus, usankcjonowaną pragnieniem cierpliwego odsłaniania coraz bardziej skrytych warstw prawdy.

Podmiot, wybierając dziedzinę myśli, dokonuje wyboru, który sytuuje go w przestrzeni etycznej. Zajmuje pozycje „pośpiechu etycznego” albo pozycje „opóźniania”, i właśnie te gesty czynia go albo pozytywnie myślącym uczonym, albo filozofem. Mimo podobieństw łączących przedmioty ich badawczej troski te pozycje są nie do pogodzenia. Ruch „etycznego pośpiechu” nie może być jednocześnie ruchem „opóźniania”.

\footnotetext{
5 Uznaje to w znanym tekście Philosophie als strenge Wissenschaft, gdzie pisze: „pod naciskiem konieczności życiowej, wobec praktycznego przymusu, by zająć stanowisko, człowiek nie mógł - być może całe tysiąclecia czekać, aż nauka przyjdzie mu z pomocą, zakładając, że miałby już ideę nauki ścisłej" (cyt. za: Derrida 2004, 278).
} 


\section{Pamięć w drodze od ontologii do etyki}

Czas dekonstrukcji, dominującej w filozoficznej myśli końca dwudziestego wieku, poddał rewizji wiele założeń, w 1967 roku jeszcze oczywistych. Z naszego punktu widzenia, punktu widzenia uwzględniającego osłabienie paradygmatu „naukowości” w humanistyce, najważniejsza była krytyka wszelkiego myślenia całościującego, tego, co nazwane zostało przez Jeana-François Lyotarda „wielkimi narracjami”. Krytyka coraz ogólniejszych pól symbolicznych, tożsamych ze strukturami, mającymi być podglebiem... wszystkiego. Jednolite, fundujące wszystkie ,ziemski[e] warstw[y] rzeczywistości i wszystki[e] niebieski[e] sfer[y] wyobraźni” pole symboliczne zaczęło się rozpadać i pękać. Narracja spójnej, naukowej racjonalności oraz prymat przyszłości - dwa fundamenty, na których opierała się nowożytna ontologia i metodologia nauk - zostały poddane zasadniczej krytyce, w której z jednej strony wykazywano arbitralny charakter tych konstrukcji, powiązany z interesami wypowiadających się podmiotów, z drugiej - przedstawiano pewien rodzaj alternatywy. Mikronarracje, różnica, inność i gościnność, wyrwanie refleksji humanistycznej z paradygmatu tradycyjnie rozumianej „naukowości” oderwanej od „wartościowania”; wszystko to i wiele innych elementów miało wyprowadzić ówczesna „,współczesność” poza diaboliczną „dialektykę oświecenia”.

Pewien fragment pracy Giorgio Agambena pokazuje ambiwalencję tkwiąca w poszukiwaniu różnicy. Inność, obcość, akcent postawiony na tym, co znajduje się poza systemem, ustanawiają bowiem jednocześnie wyjątek, porzucenie. W Homo sacer autor zauważa: „relacja porzucenia jest bowiem tak niejasna, że nic nie jest trudniejsze niż zerwanie z nią" (Agamben 2008, 151). Raz ustanowiony - wyjątek trwa. Ale nie jest całkiem osobny. „Wyrzucenie jest zasadniczo władzą przywrócenia czegoś samemu sobie, czyli władzą utrzymywania się $\mathbf{w}$ relacji z uprzednio założonym nieodniesieniem [podkreśl. AL]” (Agamben 2008, 151). Słowa te są dziwnie podobne w duchu do rozpoczynającego nasz tekst motta z Encyklopedii nauk filozoficznych Hegla. Do tej myśli wrócimy, by odnaleźć miejsce przekroczenia opozycji tego, co historyczne, i tego, co strukturalne.

Wcześniej jednak zauważymy, że an-archiczny charakter poststrukturalizmu niósł ze sobą jeszcze inny niepokojący ton, dysonansową muzykę, której intuicję uchwycić próbował James Berger w swojej książce o myśli postapokaliptycznej:

Biorąc pod uwagę zrozumiałą i powszechną skłonność do unikania tak niedawnej i przemożnej grozy, nie jest zaskakujące to, że również teoria poststrukturalistyczna w późnych latach sześćdziesiątych i wczesnych siedemdziesiątych (tak we Francji jak Stanach Zjednoczonych) pomijała Holokaust. Jednak z perspektywy czasu uderza to, że owemu pominięciu najważniejszej, najbardziej traumatycznej przemocy stulecia 
towarzyszyło nasilenie apokaliptycznej retoryki, wypełnionej przywoływaniem zerwania, utraty Centrum, fragmentacji, nieodwracalnej utraty tożsamości, zdruzgotaniem źródeł i celów (Berger 1999, 107).

W braku „źródeł i celów”, który charakteryzował teorię poststrukturalistyczną, Berger odnalazł mechanizm obronny, który służyć miał maskowaniu wspomnienia skrajnie traumatycznego doświadczenia dwudziestego wieku. Język teoretyczny wypracowany w dziewiętnastym stuleciu i obowiązujący jeszcze przez pięćdziesiąt lat nie był zdolny odnieść się do tego doświadczenia, a jednocześnie nie mógł go już ignorować. Wypowiadał je więc przez melancholijną negację wszystkiego, co nie było tą Rzeczą, nigdy tego nie wypowiadając.

Czy więc poststrukturalizm był swego rodzaju „epoką schyłkową”? Czy dekonstruując nowożytną wiarę w ostateczny sens historii i w moralną prawomocność nauk pozytywnych, umieścił nas w melancholijnej pozycji, w której pozostaje nam tylko pamiętanie? „Pamiętanie nabożne” - jak to nazywa Ágnes Heller ${ }^{6}$ - które pod koniec dwudziestego stulecia etyczną prawomocność wszelkiej teorii czerpie z przemyślenia przeszłości, zawsze z przemyślenia przeszłości i tylko z tego?

To w tym momencie następowała aktualizacja powstałej w latach trzydziestych Benjaminowskiej figury anioła historii. Zawsze warta przypominania, z naszego punktu widzenia najpełniej oddaje ów ruch, w którym historia, jeszcze przed momentem będąca ontologią bytu społecznego, przekształca się w „nabożne pamiętanie”, mające w gruncie rzeczy charakter pozycji etycznej.

\begin{abstract}
Twarz zwrócił ku przeszłości. Gdzie nam ukazuje się łańcuch wydarzeń, on widzi jedną wielką katastrofę, która nieustannie piętrzy gruzy i ciska mu je pod nogi. Chciałby może się zatrzymać, pobudzić umarłych i złączyć to, co rozbite. Lecz od raju wieje wicher, który zaplątał mu się w skrzydła i jest tak potężny, że anioł nie może ich już złożyć. Wicher ten gna go niepowstrzymanie w przyszłość, do której zwrócony jest plecami, podczas gdy przed nim po same niebo rosną zwaliska gruzów. To, co my nazywamy postępem, to ten właśnie wicher (Benjamin 2012, 316).
\end{abstract}

\footnotetext{
6 „,...] Wspomnienie jako nabożeństwo - nabożne pamiętanie tego, co się stało tutaj w Europie zobowiązuje. Musimy zastanowić się nad winą tej tak atrakcyjnej nadziei i tych tak wzniosłych myśli - musimy odważyć się na pomyślenie demoniczności. Requiem, które odmawia się lub śpiewa za zmarłych, jest tylko wtedy szczere, gdy praca ta zostanie wykonana, praca nabożnego wspomnienia” (Heller 201, 68).
} 
Gdy w latach sześćdziesiątych nastapił zmierzch lewicowych nadziei, podstawowej formy realizowania się etycznego prymatu przyszłości, Hannah Arendt upowszechniła myśl Benjamina w świecie anglojęzycznym (Arendt 2007). Dziesięć lat później zwrot ku przeszłości, ku moralnemu prymatowi przeszłości, już się dokonał. Być może najlepiej pisał o tym francuski historyk, Pierre Nora:

\begin{abstract}
Mimo iż tradycyjna pamięć zanika, czujemy się zobowiązani do wytrwałego kolekcjonowania pozostałości, świadectw, dokumentów, obrazów, pogłosek, jakichkolwiek widzialnych znaków tego, co było, tak jakby to pęczniejące dossier miało być wykorzystane jako dowód przed nieznanym jeszcze trybunałem historii [podkreśl. AL] (Nora 2009, 4-23).
\end{abstract}

Jeśli więc jeszcze niedawno teraźniejszość sytuowała „trybunał” w przyszłości, skąd spoglądał on na przeszłość, to pod koniec wieku trybunał historii spoglądał już na nas z innego miejsca. To przeszłość mogła nas uprawomocnić w jego spojrzeniu.

Ważne jest tu jeszcze spostrzeżenie, że „tradycyjna pamięć zanika”. Nie żyjemy w niedostrzegalnej tradycji „przedłużonego średniowiecza”, zaś konsekwencją tego jest przemieszczenie kwestii pamiętania ze sfery, w której określa ona formy życia - sfery, która można nazwać ontologiczną - w sferę etyczną, przyznająca przeszłości normatywną moc.

Gdy jednak nie ma nadziei, czyli obiektu pragnienia w postaci przyszłości, gdy obiektem staje się przeszłość, może ona obudzić się w postaci teraźniejszego kultu demonów. Przestrzega przed tym Nora: „rewindykowanie pamięci jest w swej zasadzie wołaniem o sprawiedliwość. W swych skutkach stawało się często wezwaniem do mordu” (Nora 2009, 43).

\title{
V. Przekroczenie dylematu
}

Powtórzmy dotychczasowe ustalenia. Oto strukturalizm wyłania się w dwudziestym wieku jako pewna „ontologia bytu społecznego”, „luzująca” dotychczas dominujące formy historyzmu. Ta zmiana wiąże się z utratą przyszłości jako źródła uprawomocnienia. Strukturalizm swoją pewność czerpie więc z innego źródła, odwołuje się do autorytetu nauk pozytywnych, budząc nadzieję na nadanie prawdziwie naukowej formy humanistyce. Nadzieje takie, wypowiadane jeszcze w latach sześćdziesiątych przez Claude’a Lévi-Straussa, opierały

$7 \quad$ Amerykańskie wydanie książki miało miejsce w roku 1968. 
się na przekonaniu, że nauka ma w sobie pewien rodzaj niekwestionowanej prawomocności, której źródłem jest poszukiwanie prawdy. Jednak postępująca od późnych lat sześćdziesiątych dekonstrukcja podstawowych pojęć zachodniej metafizyki nie oszczędziła i samej prawdy. W subtelnej i przenikliwej formie wyraził to Jacques Derrida, gdy oddzielił pozycję naukowca, kierującego się „etycznym pośpiechem” czy wręcz „niecierpliwością” zmuszającą do wypowiadania pozytywnych twierdzeń, od pozycji filozofa, „odraczającego w nieskończoność udzielenie odpowiedzi”. Dodajmy, że w oczach Derridy obie postawy są etycznie uprawnione, a ich jednoczesne „mówienie” możliwe jest tylko ze względu na strukturę języka, pola symbolicznego, które jawi się jako nieuchronnie pęknięte. Ekspozycja tej różnicy splotła się ze zwróceniem ku „nabożnemu wspominaniu”, przypisującemu moralny prymat przeszłości. To wtedy rozpowszechniła się kultura pamięci, zaś cały poststrukturalizm rozpoznany został jako forma opracowania niemożliwej do wypowiedzenia traumy dwudziestego wieku.

Czy jednak rozpoznanie tego „melancholijnego” aspektu myśli końca minionego stulecia wyczerpuje moc Derridiańskiego uwolnienia postawy filozofa? Uwolnienia od terroru faktyczności, uwolnienia zaprojektowanego w geście „nieskończonego odraczania”?

Chcę postawić inną tezę. Sądzę, że wyłania się tu miejsce dla takiej filozofii, która, z jednej strony, nie będzie celebrowaniem metafizycznych uzasadnień nauk pozytywnych, z drugiej, nie wpadnie w dekonstrukcyjny „rytuał żałobny”, zakazujący myślenia, które łączy, a nie różni.

Wyłonienie tej formy filozofowania wymaga jednak kilku kroków wstępnych. Zacznijmy więc od schyłkowego charakteru ponowoczesności. „Nie ma epok upadku”, pisał Walter Benjamin (Benjamin 2005, 503). Jak rozumieć ten pozorny paradoks? Nie ma, bowiem ich istotą jest swoiste zaćmienie rozumu - to, że trudno jest uchwycić, co właściwie w takiej epoce się dzieje, skąd absurdalność czynów i słów, niewczesność zdarzeń, groteskowość ludzi. Jak w komedii, ale czarnej. To zaćmienie spowija w mroku wszystko, co dotąd wydawało się oczywiste. Benjamin medytował nad tymi zagadnieniami w Źródle dramatu żałobnego (Benjamin 2013), rozwijając pojęcie konstelacji, pewnego układu idei i wyobrażeń, które mocą wzajemnej równowagi utrzymują się i nadają sobie wzajemnie sens.

Pewna konkretna konstelacja nigdy jednak nie wyczerpuje wszystkich możliwych konstelacji. Epoki upadku to epoki, w których rządzi przemiana nieznajdująca reprezentacji w polu symbolicznym. Epoki, których panująca „ontologia bytu społecznego" nie przewidziała, dla których nie stworzyła miejsca. W których nie ma warunków ich wypowiedzenia, zaś pole symboliczne, które zapowiadaja, jawi się jako zbiór absurdalnych zakrzywień i nieciagłości, „rozszczelnienie” tego pola, które właśnie upada. 


\section{Lacanowska dygresja na temat pojęcia „rozszczelniania”}

„Rozszczelnienie” relacji bytu i uprawomocnienia, zachodzące u schyłku dwudziestego stulecia, pojawia się w refleksji Alenki Zupančič, przedstawionej w jej książce o komedii z 2008 roku - The Odd One In. Omawiając w heglowskim stylu tragedię i komedię, używa ich, by rozpisać dwie zupełnie różne strategie myślenia o istnieniu i jego legitymizacji. Czerpie je z Lacanowskiej geometrii „diagramów seksuacji”. Po męskiej stronie diagramu mamy rezultat dwóch tysięcy lat rozwoju teorii filozoficznej, łącznie z dwudziestym wiekiem. Mamy więc do czynienia z pewną całością - to onto-teologia - rozrywana przez wyjątek. To rozerwanie pola symbolicznego zawiera już w sobie wszystkie Heideggerowskie i Derridiańskie dekonstrukcyjne manewry; w nim zapisane jest ostatnie sto lat destrukcji metafizyki, tym razem opowiedziane w idiolekcie Lacana.

Tu wpisuje się też Agambenowskie: „to, co zostało objęte wyrzuceniem [...] [wyjątek właśnie - przyp. AL], jest przywrócone własnej odrębności, a zarazem jest zdane na łaskę [in bando] tego, kto porzuca, jest jednocześnie wyłączone i włączone, zwolnione i schwytane" (Agamben 2008, 151). Mamy zatem coś jeszcze: tragedię, wprowadzająca w tak pomyślaną ontologię wymiar etyczny.

W komedii jednak, sytuującej się po żeńskiej stronie, wyjątek jest rdzeniem samego pola symbolicznego, a raczej jego gwałtownej i chaotycznej - w sensie teorii chaosu transformacji. Wyjątek nie jest czymś, jakimkolwiek obiektem, jest ruchem-pozarozumieniem, poza reprezentowaniem, upadkiem filozofa, który poślizgnął się na skórce od banana, zaćmieniem rozumu. Głupotą. Mamy więc komedię z jej nieuchronnie dynamicznym charakterem, rozrywającym spójność myślenia...

Slavoj Žižek, interpretując tę sytuację, metaforycznie wykorzystuje różnicę pomiędzy opisem obiektu w szczególnej i ogólnej teorii względności:

choć szczególna teoria względności wprowadza już pojęcie zakrzywionej przestrzeni, to postrzega ona owo zakrzywienie jako efekt działania materii; to obecność materii zakrzywia przestrzeń, tzn. tylko pusta przestrzeń nie byłaby zakrzywiona. Wraz z przejściem do ogólnej teorii względności przyczynowość ta zostaje odwrócona: materia nie tylko nie powoduje już zakrzywienia przestrzeni, lecz także jest jej efektem, obecność materii sygnalizuje, że przestrzeń jest zakrzywiona (Žižek 2009, 90).

Podsumowując te dwie perspektywy: pole symboliczne, struktura, jest zawsze jakby „zakrzywione”; to w tym zakrzywieniu wyłaniają się obiekty „wszystkich ziemskich warstw rzeczywistości i wszystkich niebieskich sfer wyobraźni”, „przeciekają” one jakby w to pole 
spoza niego. Wszelka ontologia, wraz ze swą logika, jest więc polem symbolicznym, które wykrzywiane jest innym. I właśnie w tym zakrzywieniu, nieciagłości, rodzi się zdarzenie, artefakt, czyli sens albo fakt. Pole symboliczne jest zawsze - immanentnie - niespójne, „rozszczelnione” i „przeciekające”.

Ale co - i dlaczego - „przecieka” przez rozszczelnienia struktury? Przecież nie obiekty - rzeczy, zjawiska, znaczace - te są tylko efektem struktury! Ale też nie Realne, jakaś ontologicznie rozumiana transcendencja Ržeçy - to byłaby „męska”, onto-teologiczna strona diagramu, razem z całą filozofią upragnionego wyjątku. O zmianie tej Žižek pisze: „,według Lacana realne - Rzecz - to nie tylko bezwładna obecność, która zakrzywia przestrzeń symboliczną (wprowadza do niej luki i niespójności), ile raczej efekt tychże luk i niespójności” (Žižek 2009, 90).

Jeszcze raz więc: jeśli to nie pewna transcendencja przecieka przez luki i niespójności struktury, jeśli to nie obiekty i klasy obiektów, to co właściwie powoduje niespójność „symbolicznego”? Odpowiedź mogłaby brzmieć: niespójność sama, czyli Inne w symbolicznym, które jawi się zawsze jako inne symboliczne. Przez nieszczelność symbolicznego przecieka inne symboliczne, spójność struktury narusza inna struktura; to przenikanie i przeciekanie przez siebie nieadekwatnych, niespójnych ze sobą pól symbolicznych, uprawomocnianych różnymi regułami etycznymi - jak nakładanie się na siebie kłębów mgły, które przenikając się, zagęszczają i rozrzedzaja - czyni „obiekty i warstwy [...], skoro jest [wreszcie struktura] podglebiem dla wszystkich ziemskich warstw rzeczywistości i wszystkich niebieskich sfer wyobraźni”. Proces ten czyni immanencję jako taką. Tę, która nigdy nie daje się ująć w jednej ontologii.

Przez rozerwanie wszelkiego „strukturalnego opisu pewnej wiæji swiata”, tak rozumiana komedia reprezentuje konieczność uwzględnienia pewnej „transcendencji w immanencji”, a więc ujmuje niemożność zbudowania ontologii absolutnej. Alenka Zupančič wyraża to, pisząc, iż ruch komediowy „postrzega przejście materii w czystego ducha i czystego ducha w coś materialnego jako jeden i ten sam ruch, napędzany powikłaniem właściwym samej materii” (Zupančič 2008, 47).

Można jednak Zupančič zadać heglowskie pytanie o warunek możliwości dialektycznego ruchu pomiędzy antytetycznymi „momentami”, uznanymi przed chwila za takie, których logicznie nie da się połączyć. Jak komediowe „zaćmienie rozumu”, poślizgniecie się go „na skórce od banana”, jest w ogóle możliwe? Co pozwala na ów ruch logiczny pomiędzy wykluczającymi się sądami, a więc też wykluczającymi się polami symbolicznymi? Bo przecież, przypomnijmy Hegla, „[te] momenty [...] mają prawdę i rzeczywistość o tyle, o ile są oddzielone”.

Nieuchronność „owładnięcia” przez to konkretne pole symboliczne, wykluczające inne, można opisać za pomocą często wykorzystywanej przez Lacana metafory wstęgi 
Möbiusa. Wstęga ta ma tylko jedną powierzchnię, ale dwie strony. Podmiot - Lacanowska mrówka - posuwający się po niej, zawsze i nieuchronnie jest na jednej ze stron, podczas gdy druga jest dla niego niedostępna. Nigdy więc jego doświadczenie nie pozwoli mu na dostrzeżenie tego, że ma do czynienia z jedną tylko powierzchnia; jeśli jest na niej, to druga jej strona jawi mu się jako skryta.

Zadajmy zatem pytanie jeszcze inaczej: co pozwala na ustanowienie wymiaru przenikającego przeciwstawne rzeczywistości razem z ich warunkami? Co wyprowadza poza ich ontologię?

\section{Hegemoniczne ustanawianie reguł}

Pytanie jest ważkie, bowiem ludzkie poznanie, „poznanie skończone”, jest zawsze wypowiedziane w pewnej strukturze, konstelacji, polu symbolicznym, a ostatecznie ontologii. Musi znaleźć jednolitą zasadę organizującą - jednolite uprawomocnienie - by móc się prezentować. Tak jak dwa sensy tkwiące w wizualnej figurze, z których jednocześnie tylko jeden może być uchwycony ${ }^{9}$, pola symboliczne wykluczają się. Istnienie jednego jawi się z perspektywy drugiego tylko jako zakrzywienie, zerwanie generujące artefakt, błąd. W tym sensie jedno pole wobec drugiego spełnia Agambenowską formułę wyjątku: „jest jednocześnie wyłączone i włączone, zwolnione i schwytane”.

Ciagły, wszechogarniający ruch we wszelkich wymiarach, zwany przez Derridę różnia, ruch, który przedstawić sobie mógłby umysł nieskończony, pozwalałby na uchwycenie wszelkich istnień we wszelkich czasach. Dla umysłu skończonego ów ruch musi być ograniczany, umysł - albo podmiot - musi dokonać wyboru, określić swoją pozycję, by możliwa była jednoznaczność sensu, warunek wszelkiego uświadamiania sobie. Wybrać musi choćby pomiędzy opisanymi przez Derridę „etycznym pośpiechem” i „nieskończonym opóźnieniem". Ale możliwe są zapewne inne wymiary, w których dokonują się wybory. Podejrzewać można, że - podobnie jak wybór pomiędzy pozycją pozytywnego uczonego i pozycją filozofa - mają one charakter etyczny. Tworzą arenę, pole, w którym rozstrzygane jest ostatecznie - by przypomnieć Taylora - jak jawić się nam będą rzeczy.

By jednak reprezentowanie było w ogóle możliwe, sam moment wyboru jest konieczny. Znaczy to tyle, że reprezentowana konfiguracja sensów nie może zawierać w sobie wszystkich, ani nawet zbyt wielu wymiarów ruchu różni. W sferze naszych wyobrażeń,

\footnotetext{
8 W sensie, który wykłada Heidegger we wspomnianym już dziele Kant a problem metafizyki, w szczególności w paragrafie 38.

9 Jak w przypadku kaczko-zająca opisywanego przez Wittgensteina.
} 
reprezentacji, zjawisk świadomości, redukcja ruchu $\mathbf{w}$ poszczególnym polu symbolicznym ujawnia się jako zasada niesprzeczności. Zaniedbanie tej redukcji produkuje zaś paradoks.

Symboliczne rządzi ruchem przedstawień wypełniających naszą wyobraźnię. Porządek symboliczny określa więc reguły ruchu w polu znaczących. Dopóki jest się w jednym z pól, rządzi ono niepodzielnie, wykluczając inne. Nie można praktykować różnych ontologii.

Jedną z takich reguł jest czas. Już analizy Kanta dotyczące analogii doświadczenia pokazały podstawowa regułę konstrukcji formy czasowej - czas jest tym schematem, który narzucany jest przez prawo przyczynowości: „Tylko przez to więc, że poddajemy następstwo zjawisk, a więc i wszelką zmianę, prawu przyczynowości, jest możliwe samo doświadczenie, [...]" (Kant 1957, 353). Pole symboliczne organizuje się więc tak, by wydarzenia wyobrażały się przez zasady przyczynowości. Tak wyobrażone zespoły wyobrażeń stają się dla nas znaczące, stają się znaczącymi, które ponownie lączą się, wpisując w najszersze ramy pola symbolicznego. To historia tych, którzy wierzą w Historię.

Jeśli więc konstytuuje się $\mathrm{w}$ polu symbolicznym pewna zasada przyczynowości, to zakłada ona jedne związki, a wyklucza inne. Właśnie hegemonia takich reguł uniemożliwia znalezienie się jednocześnie „po dwóch stronach wstęgi Möbiusa”, konstytucję jednej pozycji podmiotowej w różnych polach symbolicznych albo - jeszcze inaczej synoptyczne ujmowanie różnych ontologii. Dlatego pisząc dzieje metafizyki, Heidegger podkreśla, że determinuje ona wszystkie znaczące zjawiska pewnej epoki. I dlatego de Saussure - pamiętacie de Saussure’a? - musiał tak zdecydowanie pisać, że albo-albo... i nie ma kompromisu.

\section{VII. „Zluzowanie” problemu historia/struktura}

Problem relacji historii i struktury, rozumiany jako konflikt metodologicznej zasady synchronicznej z zasadą diachroniczna, traci w nakreślonej tu perspektywie swoją samoistną wagę. Staje się problemem możliwości reprezentowania jednych pól symbolicznych w innych. Albo warunków możliwości ujmowania przez myśl filozoficzną różnych ontologii, swą moc czerpiących z różnych reguł uprawomocnienia.

Jeśli pewna ontologia, sposób jawienia się faktów, zawsze poddana jest zasadzie etycznej, to czeka nas praca nad wyłanianiem samych warunków możliwości zmieniania się zasad etycznych, organizujących ontologie. Czeka nas odpowiedź na pytanie, jak podmiot 
znajduje sobie pewną przestrzeń, taki wymiar, w którym wędrować może jakby poza sprzecznymi ze sobą warunkami, poza polami tych warunków. Poza istnieniem.

Albo, używając metafory wstęgi Möbiusa, zapytać możemy, jak zobaczyć jej jedność, jedność płaszczyzny immanencji. Odpowiedź brzmi: lokując się w miejscu, którego - z perspektywy wstęgi - nie ma.

Ta odpowiedź kieruje nas ku myśleniu, które fundamentalny sens filozofii lokuje właśnie „poza istnieniem”. Współgra ono z sensem całego naszego wywodu, w którym to w wymiarze etycznym nadawana jest prawomocność ontologicznym przesłankom nauk; ten wymiar czyni możliwym postawienie takich przesłanek przed jednolitym „trybunałem”, ten wymiar splata je, ale też rozszczelnia, zakrzywia je tak, że wyłaniają się z nich rzeczy i wyobrażenia.

To znaczy też, że pola symboliczne, sieci znaczących zakrzywiają się i deformuja wzajem w polu spojrzenia dwóch „nieistniejących”, pustych miejsc: podmiotu i Innego... Kwestie te wychodza jednak poza zakres tego artykułu. 


\section{Wykaz literatury}

Benjamin, Walter. 2012. „O pojęciu historii”. W Walter Benjamin. Konstelacje. Wybór tekstów. Tłum. Adam Lipszyc, Anna Wołkowicz. Kraków: Wydawnictwo Uniwersytetu Jagiellońskiego.

Agamben, Giorgio. 2008. Homo sacer. Suwerenna władza i nagie sycie. Tłum. Mateusz Salwa. Warszawa: Prószyński i S-ka.

Arendt, Hannah. 2007. Walter Benjamin. 1892-1940. Tłum. Andrzej Kopacki. Gdańsk: Wydawnictwo Słowo/obraz terytoria.

Benjamin, Walter. 2005. Pasaże. Tłum. Ireneusz Kania. Kraków: Wydawnictwo Literackie. Benjamin, Walter. 2013. Źródto dramatu żałobnego w Niemczech. Tłum. Andrzej Kopacki. Warszawa: Wydawnictwo Sic!.

Berger, James. 1999. After the end. Representations of post-apocalypse. Minneapolis: University of Minnesota Press.

Deleuze, Gilles. 1978. „Po czym rozpoznać strukturalizm?”. Tłum. Stanisław Cichowicz. W Drogi wspótcz̨esnej filozofii. Red. Marek J. Siemek. Warszawa: Czytelnik.

Derrida, Jacques. 1999. O gramatologii. Tłum. Bogdan Banasiak. Warszawa: Wydawnictwo KR.

Derrida, Jacques. 2004. „»Geneza i struktura« a fenomenologia”. W Jacques Derrida. Pismo $i$ różnica. Tłum. Krzysztof Kłosiński. Warszawa: Wydawnictwo KR.

Descombes, Vincent. 1997. To samo i inne. Czterdzieści pię́ lat filozofii francuskiej (1933-1978). Tłum. Bogdan Banasiak, Krzysztof Matuszewski. Warszawa: Wydawnictwo Spacja.

Ferry, Luc i Alain Renaut. 1990. French Philosophy of the Sixties An Essay on Antihumanism. Tłum. Mary H.S. Cattani. Amherst: University of Massachusetts Press.

Habermas, Jürgen. 2000. Filozoficzny dyskurs nowoczesności. Tłum. Małgorzata Lukasiewicz. Kraków: Universitas.

Hegel, Georg W.F. 1990. Encyklopedia nauk filozoficznych. Tłum. Światosław F. Nowicki. Warszawa: PWN.

Heidegger, Martin. 1989. Kant a problem metafiayki. Tłum. Bogdan Baran. Warszawa: PWN. Heller, Ágnes. 2001. „Requiem dla stulecia”. Tłum. Katarzyna Leszczyńska. Przeglad Polityczny 51.

Kant, Immanuel. 1957. Krytyka czystego rozumu. Tom I. Tłum. Roman Ingarden. Warszawa: PWN.

Kosseleck, Reinhardt. 2001. „»Przestrzeń doświadczenia«i »horyzont oczekiwań« - dwie kategorie historyczne". W Reinhardt Kosseleck. Semantyka bistoryczna. Tłum. Wojciech Kunicki. Red. Wojciech Orłowski. Poznań: Wydawnictwo Poznańskie.

Lévi-Strauss, Claude. 1970. „Analiza strukturalna w językoznawstwie i antropologii”. W Claude Lévi-Strauss. Antropologia strukturalna. Tłum. Krzysztof Pomian. Warszawa: Państwowy Instytut Wydawniczy.

Nora, Pierre. 2009. „Między pamięcią i historią. Lieux de Mémoires”. Tłum. Paweł Mościcki. Tytut robocsy: Archiwum 2: 4-23.

Taylor, Charles. 2001. Źródła podmiotowości. Narodziny tożsamości nowoczesnej. Tłum. Marcin Gruszczyński i in. Warszawa: PWN.

Žižek. Przewodnik krytyki politycznej. 2009. Warszawa: Wydawnictwo Krytyki Politycznej. Zupančič, Alenka. 2008. The Odd One In. On Comedy. Cambridge-London: MIT Press. 
Andrzej Leder - urodzony w 1960 roku, doktor habilitowany, profesor w Instytucie Filozofii i Socjologii PAN. Wydał rozprawy filozoficzne: Nieświadomość jako pustka. Wokót myśli Freuda i Husserla, oraz Nauka Freuda w epoce „Sein und Zeit”, pracę na temat historii Polski: Prześniona rewolucja. Ćwiczenie z logiki bistorycznej, rozprawę dotyczącą idei filozoficznych w dwudziestowiecznej Europie: Rysa na tafli. Teoria w polu psychoanalitycznym, a także, po angielsku: The Changing Guise of Myths. Naucza w Szkole Nauk Społecznych IFiS PAN i w Collegium Civitas. Mieszka w Warszawie.

\section{DANE ADRESOWE:}

Zespół Filozofii Kultury

Instytut Filozofii i Socjologii PAN

ul. Nowy Świat 72

00-330 Warszawa

EMAIL: aleder@ifispan.waw.pl

CYTOWANIE: Leder, Andrzej. 2016. Historia i struktura. Problem uprawomocnienia. Praktyka Teoretyczna 4 (22): 132-151.

DOI: $10.14746 /$ prt.2016.4.7

\section{AUTHOR: Andrzej Leder}

TITLE: History and structure. A problem of legitimization.

ABSTRACT: In his text the author is defining the conflict of the structuralist and historicist - synchronic and diachronic thought - described by de Saussure-- as a development of two different ethical axioms in the field of social philosophy. He tries to show, how each of this axioms can generate a different ontology of social being. Applying some elements of Deleuzian thought the author analyzes the theoretical position of the two ethical axioms. Then, on the fundament of the Lacanian, and more generally poststructuralist thought he tries to give a draft of a theoretical space in which such a change of ethical positions would be possible. He develops thus a new philosophy of symbolic fields.

KEYWORDS: de Saussure, Deleuze, Benjamin, history, structure, ethics, symbolic field 